\title{
Pengembangan Produk Bakso yang Berbahan Baku Berantioksidan
}

\author{
Wellyalina $^{1}$, Daimon Syukri ${ }^{1}$ \\ ${ }^{1}$ Universitas Andalas, Limau Manis, Kec.Pauh, Kota Padang, 25175, Indonesia
}

\section{INFORMASI ARTIKEL}

\section{Sejarah Artikel:}

Diterima Redaksi: 10 Juni 2020

Revisi Akhir: 27 Juni 2020

Diterbitkan Online: 30 Juni 2020

\section{KATA KUNCI}

pengembangan produk, bakso, tanaman antiosidan, antioksidan

\section{KORESPONDENSI}

Wellyalina

E-mail: wellyalina@ae.unand.ac.id

\begin{abstract}
A B S T R A C T
The development of functional food is increasing. Meatball is a popular food product that can be developed to be more functional by adding antioxidants. Meatballs are processed products from small round meat. This study aims to obtain the best formula for meatball production with high antioxidant content and good organoleptic characteristics. The addition of Moringa leaves, celery, panax cup leaves, and lime leaves to the original meatball production formula was used as a treatment in this study. The research method uses an exploratory method through laboratory experiments. The treatment used was the addition of Moringa leaves, celery, bowl, and lime leaves. Each treatment was added with a different main ingredient as much as $3.3 \%$ with 3 repetitions so that the results can be said to be valid. The results showed that the addition of panax cup leaves could produce functional meatballs with the best antioxidant and organoleptic properties among all treatments.
\end{abstract}

\section{PENDAHULUAN}

Pengembangan produk adalah suatu kegiatan atau aktifitas yang dilakukan dalam menghadapi kemungkinan perubahan suatu produk ke arah yang lebih baik sehingga dapat memberikan daya guna maupun daya pemuas yang lebih besar. Pengembangan produk terdiri dari produk pangan dan non pangan. Dalam pengembangan produk haruslah memenuhi kriteria seperti produk yang benar-benar baru (belum pernah ada sebelumnya), hasil modifikasi produk yang sudah ada, dan hasil meniru produk yang sudah ada. Alasan utama melakukan pengembangan produk adalah meningkatkan nilai dari suatu produk dan memperoleh keuntungan baik dari segi materi maupun kesehatan tambahan seperti pangan fungsional. [1].

Bakso merupakan produk olahan dari daging yang berbentuk bulat kecil dan dapat dimakan secara langsung atau diolah terlebih dahulu. Bakso terbuat dari (daging sapi / daging ayam / daging ikan) yang dicincang atau digiling dengan campuran tepung tapioka, es batu dan bumbu-bumbu sebagai penyedap. Bahan bahan tersebut dicampur hingga membentuk adonan yang kalis kemudian dibentuk bulat dan direbus. Bakso merupakan salah satu olahan daging yang sangat terkenal dan digemari oleh semua lapisan masyarakat, karena memiliki rasa yang khas, enak, dan kaya zat gizi. Bakso memiliki kandungan protein dan kadar air tinggi serta $\mathrm{pH}$ netral, sehingga rentan terhadap kerusakan dan daya awet maksimal 1 hari pada suhu kamar. Bahan baku bakso dapat berasal dari berbagai jenis daging ternak, seperti : sapi, ayam dan ikan [2]. Namun, pada bahan baku pengolahan bakso tidak hanya protein hewani saja tetapi bisa juga dengan tanaman berantoksidan yang kaya akan manfaat.

Pemanfaatan tanaman berantioksidan biasanya dimanfaatkan sebagai bahan baku minuman tradisional yang tidak hanya berfungsi sebagai minuman penyegar, tetapi juga sebagai minuman yang memiliki segi fungsional bagi kesehatan. Antioksidan dibutuhkan untuk melindungi tubuh dari serangan radikal bebas. Antioksidan adalah suatu senyawa atau komponen kimia yang dalam kadar atau jumlah tertentu mampu menghambat atau memperlambat kerusakan akibat proses oksidasi. Tubuh manusia tidak mempunyai cadangan antioksidan dalam jumlah berlebih, sehingga apabila terbentuk banyak radikal maka tubuh membutuhkan antioksidan eksogen. Adanya kekhawatiran kemungkinan efek samping yang belum diketahui dari antioksidan sintetik menyebabkan antioksidan alami menjadi alternatif yang sangat dibutuhkan. Beberapa tanaman berantioksidan kaya manfaat yang digunakan dalam pengolahan pangan seperti daun kelor, seledri, mangkok, dan daun jeruk [3]. Pemakaian daun kelor, seledri, mangkok, dan daun jeruk Biasanya sebagai penambah citarasa bahan pangan. maka dari itu, peneliti menggunakan daun kelor, seledri, mangkok, dan daun jeruk sebagai olahan lanjutan seperti bakso. Bahan pangan tersebut mudah didapatka dan relative murah.

Di Indonesia pemanfaatan kelor masih belum banyak diketahui, umumnya hanya dikenal sebagai salah satu menu 
sayuran. Selain di konsumsi langsung, kelor juga dapat diolah menjadi bentuk tepung. Selanjutnya dapat digunakan sebagai bahan fortifikan untuk mencukupi nutrisi pada berbagai produk pangan, seperti olahan pudding, cake, nugget, biscuit, cracker serta olahan lainnya [4].

Asupan antioksidan setiap hari dapat mengurangi peluang munculnya gejala penyakit degeneratif dan mampu memperlambat penuaan. Seledri (Apium graveolens) merupakan salah satu tumbuhan dengan kandungan antioksidan tinggi. Seledri tidak memiliki efek samping untuk tubuh kita, mudah didapat dan harganya pun terjangkau untuk semua kalangan. Tanaman Seledri merupakan tumbuhan yang memiliki khasiat sebagai bahan obat tradisional yang memiliki efek anti hipertensi, diuretik ringan dan antiseptik pada saluran kemih serta antirematik. Selain itu uji pendahuluan tanaman ini mampu menurunkan tekanan darah pada hewan uji [5].

Tanaman mangkokan murah dan mudah ditemukan, masyarakat secara turun temurun menggunakan tanaman mangkokan sebagai obat tradisional. Supaya pengobatan secara tradisional dapat dipertanggung jawabkan maka perlu didukung oleh informasi ilmia mengenai kandungan aktif tanaman mangkokan. Salah satu tumbuhan yang telah diteliti adalah daun mangkokan, yang mengandung kalsium oksalat, peroksidase, amigdalin, fosfor, besi, lemak, protein, vitamin A, B1, C, saponin, tannin dan flavonoid. Jenis flavonoid yang terkandung di dalam daun mangkokan adalah flavonol (kuersetin, kaempferol dan mirisetin) dan flavon (luteolin dan apigenin) yang diduga memiliki aktivitas antioksidan [6]. Aktivitas antioksidan tertinggi, yakni sebesar $23,03 \%$ pada waktu inkubasi 72 jam. Waktu inkubasi sangat berpengaruh terhadap peningkatan aktivitas antioksidan metode tiosianat. Fraksi kloroform mempunyai nilai IC50 terbesar, yakni 19,58 ppm [9].

Jeruk nipis (Citrus aurantifolia s.) adalah salah satu tanaman toga yang banyak digunakan oleh masyarakat sebagai bumbu masakan dan obat-obatan. Dalam bidang medis, jeruk nipis dimanfaatkan sebagai penambah nafsu makan, diare, antipireutik, antiinflamasi, antibakteri dan diet. Jeruk nipis memiliki kandungan flavonoid, saponin dan minyak atsiri. Komponen minyak atsirinya adalah siral, limonene, feladren, dan glikosida hedperidin. Sari buah jeruk nipis mengandung minyak atsiri limonene dan asam sitrat $7 \%$. Buah jeruk mengandung zat bioflavonoid, pectin, enzim, protein, lemak dan pigmen (karoten dan klorofil) [7].

Pada penelitian terdahulu, beberapa tanaman yang mengandung antioksidan tinggi seperti daun kelor, seledri, mangkok, dan daun jeruk digunakan sebagai sayuran segar ataupun campuran aneka olahan masakan gulai dengan beberapa konsentrasi yang ditambahkan. Berdasarkan uraian diatas, pada penelitian ini dilakukan pengembangan produk berbahan baku tanaman berantioksidan seperti bakso. Penelitian ini dilakukan untuk mendapatkan formula terbaik pada pengembangan produk bakso dengan antioksidan tinggi dan juga memiliki karakteristik organoleptik yang baik.

\section{METODOLOGI}

Penelitian ini dilakukan di Laboratorium Instrumen PusatTeknologi Hasil Pertanian Fakultas Teknologi Pertanian
Universitas Andalas dari bulan Januari-Februari 2020. Bahan baku yang digunakan adalah daging sapi, seledri, daun kelor, daun mangkok, dan daun jeruk nipis. Bahan kimia yang digunakan adalah metanol, DPPH, dan aquades.

Metode penelitian menggunakan metode eksploratif melalui eksperimen di laboratorium. Perlakuan yang digunakan adalah penambahan daun kelor, seledri, mangkok, dan daun jeruk nipis. Setiap satu perlakuan ditambahkan satu bahan utama yang berbeda sebanyang 3,3\% dengan 3 kali ulangan sehingga hasil dapat dikatakan valid.

Prosedur dalam pembuatan bakso dengan penambahan tanaman berantioksidan termasuk kontrol sebagai berikut: (1) siapkan bahan sesuai formula yang dimodifikasi bahan utama daun kelor, seledri, mangkok, dan daun jeruk nipis $3,3 \%$, daging $65,4 \%$, tapioka $13,1 \%$, garam $1.6 \%$, merica $0,65 \%$, bawang goreng $1,96 \%$, bawang putih $3.3 \%$, penyedap $0,65 \%$, es batu $6,54 \%$, telur $3,6 \%$, (2) semua bahan digiling dengan menggunakan mesin penggiling daging, (3) didihkan air untuk merebus bakso, (4) ambil adonan kemudian bulatkan dimasukan kedalam air didih tersebut, (5) angkat bakso yang telah mengapung, (6) tiriskan.

Pengujian bakso berantioksidan dilakukan beberapa uji yaitu organoleptik, kadar air, dan antioksidan.

Uji organoleptik merupakan uji dengan menggunakan indera manusia sebagai instrumennya. Uji ini adalah uji hedonik (uji kesukaan) oleh 25 panelis. Uji organoleptik yang dilakukan adalah uji penerimaan yaitu setiap panelis diharuskan mengemukakan tanggapan tentang produk yang disajikan. Tujuan dari uji ini adalah untuk mengetahui produk yang lebih disukai. Pada uji panelis diminta mengungkapkan tanggapan pada rasa, aroma, tekstru, dan warna. Skala yang digunakan menggunakan 7 skala numerik yaitu sangat suka (7), suka (6), agak suka (5), biasa saja (4), agak tidak suka (3), tidak suka (2), sangat tidak suka (1).

Menetapkan kadar air (AOAC, 2005) merupakan cara untuk mengukur banyaknya air yang terdapat di dalam suatu bahan pangan. Metode pengeringan dengan metode oven ini berprinsip pada pengukuran kehilangan berat akibat menguapnya air dari bahan yang dikeringkan pada suhu $100-102^{\circ} \mathrm{C}$.

Kadar air $(\%$ wet basis $)=\frac{\mathrm{W} 1-(\mathrm{W} 2-\mathrm{W} 0)}{\mathrm{W} 1} \times 100 \%$

Kadar air $(\%$ dry basis $)=\frac{\text { W1-(W2-W0 })}{\mathrm{W} 1} \times 100 \%$

Total solid $(\%)=$ $\frac{\mathrm{W} 1-(\mathrm{W} 2-\mathrm{W} 0)}{\mathrm{W} 1} \times 100 \%$

Keterangan : $\quad$ W0 $=$ Cawan kosong beserta tutupnya $\mathrm{W} 1$ = Cawan berisi sampel W2 = Cawan berisi sampel yang

8 Wellyalina et al. 
didinginkan dalam desikator

Metode penangkapan radikal bebas stabil DPPH (AOAC, 2005) dipilih karena metode ini dapat mengukur kapasitas antioksidan semua jenis substrat dalam sampel, baik substrat yang bersifat hidrofilik maupun lipofilik sehingga diharapkan dapat menghasilkan hasil pengukuran yang lebih baik. Sampel ditimbang $1 \mathrm{~g}$ kemudian dimasukan kedalam tabung reaksi, tambahkan $10 \mathrm{ml}$ metanol, vortek, dan ultrasonik selama 15 menit. Dipipet $1 \mathrm{ml}$ sampel dimasukan kedalam tabung reaksi yang berbeda ditambahkan $1 \mathrm{ml}$ DPPH kemudian buat blanko. Tunggu 15 menit dan baca pada gelombang $517 \mathrm{~nm}$ dengan spektrofotometer.

$\%$ inhibisi $=\frac{\text { A blangko-A sampel }}{\text { A blangko }} \times 100 \%$

\section{HASIL DAN PEMBAHASAN}

\section{Uji Organoleptik}

Secara umum penilaian organoleptik dapat dilakukan rekapitulasi nilai suka, sangat suka, dan amat sangat suka terhadap produk bakso yang dilakukan pengujian satu kali dengan 25 orang panelis seperti yang disajikan pada Tabel 1 .
Tabel 1. Rekapitulasi Data Organoleptik Bakso Berantioksidan

\begin{tabular}{lcccc}
\hline Perlakuan & Rasa & Aroma & Tekstur & Warna \\
\hline A= kontrol & 5 & 5 & 7 & 5 \\
B= seledri & 6 & 6 & 5 & 6 \\
C= daun kelor & 6 & 6 & 5 & 5 \\
D= daun mangkok & 7 & 7 & 5 & 7 \\
E= daun jeruk nipis & 6 & 7 & 5 & 5 \\
\hline
\end{tabular}

Keterangan: nilai meliputi $7=$ amat sangat suka, $6=$ sangat suka, $5=$ suka, 4=agak suka, 3=tidak suka, 2=sangat tidak suka, 1=amat sangat tidak suka

Tabel 1 merupakan data penilaian panelis terhadap bakso berantioksidan yang dihasilkan, dimana nilai di atas merupakan penjumlahan parameter suka, sangat suka, dan amat sangat suka. Rasa tertinggi terdapat pada perlakuan D dengan penambahan daun mangkok, aroma tertinggi terdapat pada dua perlakuan yaitu perlakuan D dan E dengan penambahan daun mangkok dan daun jeruk nipis, tekstur tertinggi terdapat pada perlakuan A tanpa penambahan bahan baku (kontrol), sedangkan warna tertinggi pada perlakuan dengan penambahan daun mangkok.

Secara keseluruhan penilaian panelis terhadap produk bakso berantioksidan menyukai perlakuan D (penambahan daun mangkok), hal ini terlihat pada perlakuan D (penambahan daun mangkok) memiliki nilai tertinggi pada 3 parameter yaitu rasa, aroma, dan warna. Radar rekapitulasi organoleptik bakso berantioksidan dan bakso berantioksidan dapat dilihat pada Gambar 1 dan 2.

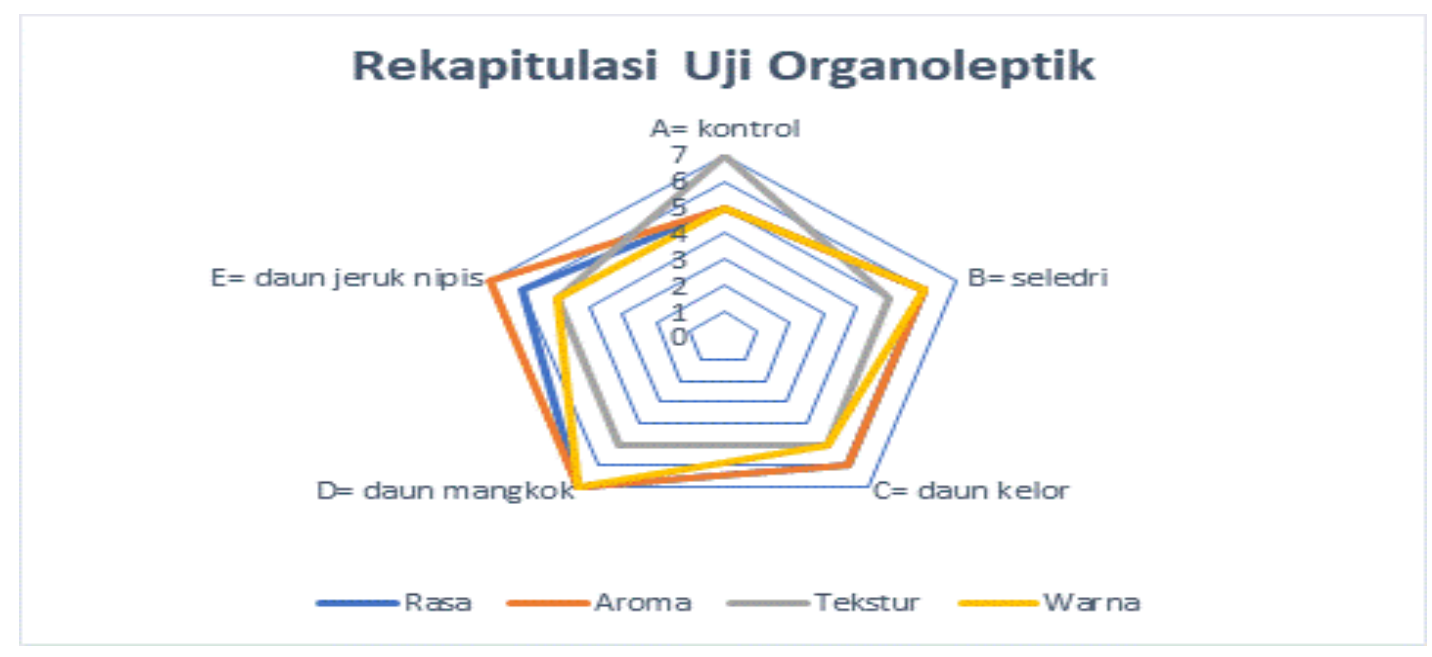

Gambar 1. Rekapitulasi Uji Organoleptik 


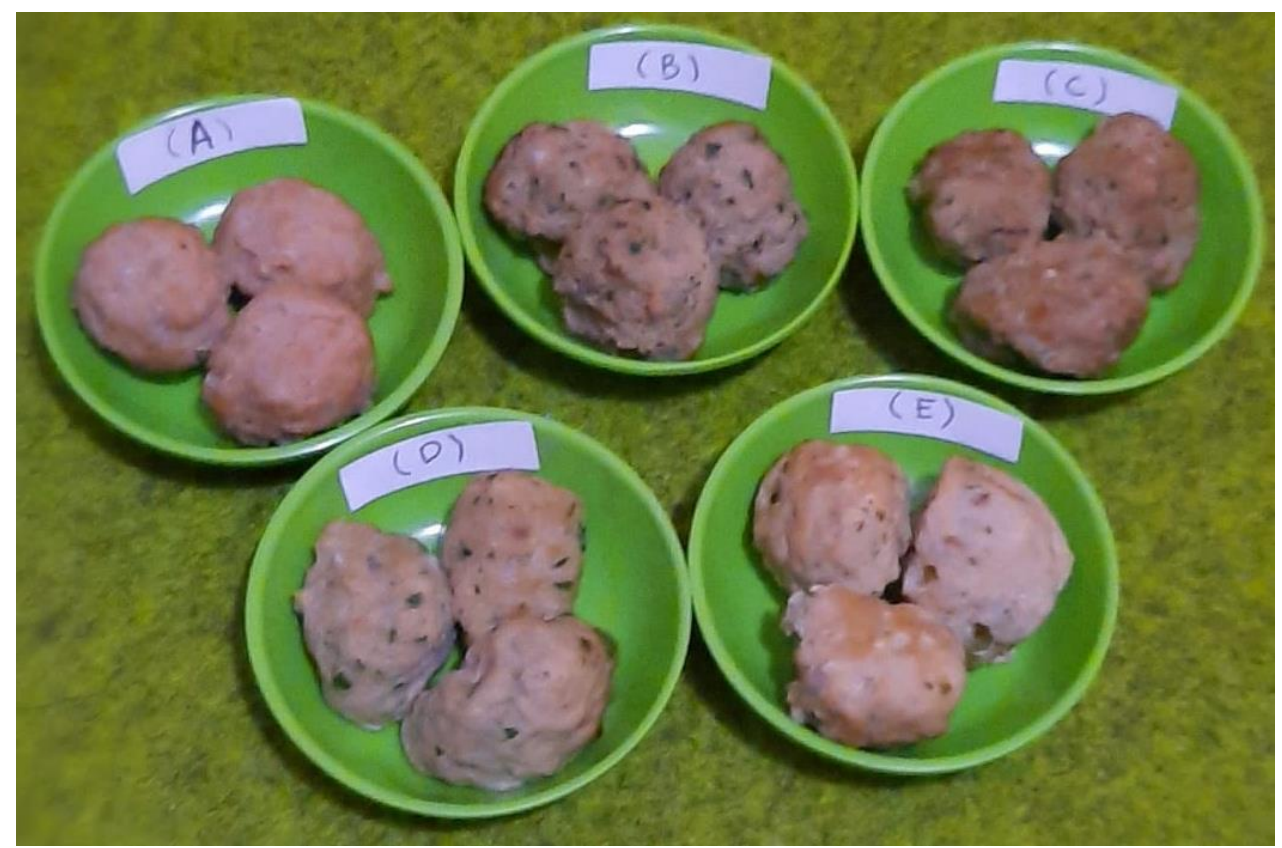

Gambar 2. Bakso Berantioksidan

Rasa merupakan parameter yang paling berperan dalam penerimaan konsumen terhadap suatu produk. Rasa juga merupakan faktor kedua yang menentukan cita rasa makanan setelah penampilan makanan itu sendiri, apabila penampilan makanan yang disajikan merangsang saraf melalui indera penglihatan sehingga mampu membangkitkan selera untuk mencicipi makanan itu [3]. Pada parameter aroma nilai tertinggi oleh perlakuan D dan E, diduga karena penambahan daun mangkok atau jeruk nipis, maka bau aromatik begitu kuat dan tajam, dan menguapnya senyawa volatil yang cukup banyak. Sedangkan warna dinyatakan bahwa klorofil adalah pigmen berwarna hijau yang terdapat dalam kloroplas. Dalam kloroplas, pigmen utama klorofil serta karotenoid dan xantofil terdapat pada membran tilakoid. Musrin melaporkan bahwa warna hijau disebabkan karena klorofil pada daun terlarut [5].

\section{Kadar Air}

Air merupakan komponen penting dalam pangan. Air dalam pangan berperan dalam mempengaruhi tingkat kesegaran, stabilitas, keawetan, dan kemudahan terjadinya reaksi-reaksi kimia, aktifitas enzim, dan pertumbuhan mikroba. Hasil analisis uji kadar air terhadap bakso daging dengan penambahan beberapa tanaman berantioksidan menunjukkan bahwa setiap perlakuan memiliki perbedaan.

Tabel 2. Perbandingan Kadar Air Bakso Berantioksidan

\begin{tabular}{lc}
\hline Perlakuan & Kadar Air (\%) \\
\hline $\mathrm{A}=$ kontrol & 17,8 \\
$\mathrm{~B}=$ seledri & 9,3 \\
$\mathrm{C}=$ daun kelor & 4,6 \\
$\mathrm{D}=$ daun mangkok & 6,4 \\
$\mathrm{E}=$ daun jeruk nipis & 2,5 \\
\hline
\end{tabular}

Dari lima perlakuan yang memiliki kadar air paling tinggi terdapat pada perlakuan A yaitu tanpa penambahan/kontrol sebesar $17,8 \%$. Hal ini terjadi disebabkan oleh tidak adanya pemberian bahan baku utama tambahan tanaman berantioksidan sehingga tidak ada terjadi pengikat air pada bakso. Sedangkan perlakuan B, C, D, E memiliki kadar air rendah dar perlakuan A. Hal ini terjadi karena adanya pemberian bahan baku utama yang berserat sehingga terjadi pengikat air pada bakso. Hasil analisis kadar air terhadap semua perlakuan telah memenuhi syarat mutu bakso pada umumnya yang menyatakan bahwa nilai kadar air bakso maksimal 70,0\% sehingga kadar air bakso dengan penambahan beberapa tanaman berantioksidan yang dihasilkan memenuhi persyaratan mutu dan keamanan pangan [8].

\section{Aktifitas Antioksidan}

Hasil analisa aktifitas antioksidan menunjukkan bahwa perbedaan perlakuan pada bakso memberikan perbedaan nilai yang berbeda terhadap persentase inhibisi.

Tabel 3. Perbandingan Aktifitas Antioksidan Bakso Berantioksidan

\begin{tabular}{lc}
\hline Perlakuan & Aktifitas Antioksidan (\% inhibisi) \\
\hline A = kontrol & 7,5 \\
$\mathrm{~B}=$ seledri & 19,8 \\
$\mathrm{C}=$ daun kelor & 20,2 \\
$\mathrm{D}=$ daun mangkok & 31,0 \\
$\mathrm{E}=$ daun jeruk nipis & 18,9 \\
\hline
\end{tabular}

Sebagaimana ditampilkan pada Tabel 3 bahwa persentase inhibisi tertinggi terdapat pada perlakuan D dan C. Persentase inhibisi yaitu perbandingan antara selisih dari absorbansi blanko dan absorbansi sampel dengan absorbansi blanko. Persentase inhibisi digunakan untuk menentukan persentase hambatan dari suatu bahan yang dilakukan terhadap senyawa radikal bebas. Nilai tertinggi pada aktifitas antioksidan sebesar 
$31,0 \%$ dimiliki oleh perlakuan penambahan daun mangkok pada pengembangan produk bakso. Hal ini di dukung juga oleh penelitian lain yang menyatakan bahwa daun mangkokan mengandung flavonoid dan saponin. Fraksi air memiliki aktivitas antioksidan tertinggi, pada waktu inkubasi 72 jam. Waktu inkubasi sangat berpengaruh terhadap peningkatan aktivitas antioksidan metode tiosianat. Diduga jenis flavonoid pada fraksi kloroform memiliki struktur paling baik dalam menangkap radikal bebas dibandingkan flavonoid dari fraksi lainnya [9], kemudian nilai tertinggi berikutnya disusul oleh daun kelor sebesar 20,2\%. Berdasarkan penelitian bahwa daun kelor juga mengandung fenolik dalam jumlah yang banyak dikenal sebagai penangkal radikal bebas [4]. Antioksidan adalah senyawa-senyawa yang mampu menghilangkan, membersihkan, menahan pembentukan ataupun meniadakan efek radikal bebas.

\section{KESIMPULAN}

Dari penelitian yang telah dilakukan maka dapat diperoleh kesimpulan sebagai berikut :

1. Pengembangan produk pada formulasi bakso terbaik dari segi organoleptik terlihat pada perlakuan D (penambahan daun mangkok) memiliki nilai tertinggi pada 3 parameter yaitu rasa, aroma, dan warna. Sedangkan pada parameter tekstur yang terbaik pada perlakuan A (kontrol) tanpa penambahan tanaman berantioksidan.

2. Aktifitas antioksidan pada penambahan daun mangkok terhadap pengembangan produk bakso menunjukkan paling tinggi dibandingkan seledri, daun kelor, dan daun jeruk nipis. Hal ini diduga jenis flavonoid pada fraksi kloroform memiliki struktur paling baik dalam menangkap radikal bebas dibandingkan flavonoid dari fraksi lainnya.

\section{ACKNOWLEDGEMENT}

Ucapan terima kasih ditujukan kepada pihak-pihak yang telah membantu pelaksanaan penelitian baik pihak proses pengolahan maupun pihak teknisi laboratorium.

\section{DAFTAR PUSTAKA}

[1] Wellyalina dan Rasdiana, Felga Zulfia. Modul praktikum pengembangan produk. Universitas Andalas. 2020.

[2] Latif, Sri Irianti. "Inovasi Bakso dari Ikan Gabus (Channa Striata) dengan Substitusi Daun Kelor (Moringa Oleifera) dan Wortel (Daucus Carota)". Internet: http://eprints.unm.ac.id/11222/1/ARTIKEL\%20SRI\%20I RIANTI.pdf, 2018 [Jul. 09, 2020].

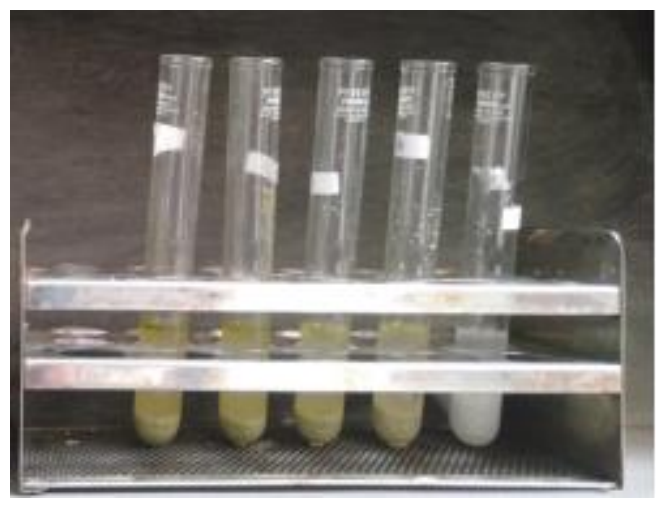

Gambar 3. Uji Antioksidan

[3] Zulfayan, et al. "Aktifitas Antioksidan Wedang Jahe Instan Menggunakan Nira Tebu sebagai Pemanis". Unes Journal Mahasiswa Pertanian, Volume 2, Issue 1, October 2018 , http://faperta.ojs.unespadang.ac.id/index.php/UJMP.

[4] Wulandari, Cici. "Pemanfaatan Bubuk Daun Kelor sebagai Pengawet Alami terhadap Mutu Kue Lapis". Tugas Akhir, Universitas Ekasakti, Padang, 2019.

[5] Musrin T, et al. "Kajian Pembuatan Pangan Fungsional dalam Bentuk Sirup dari Ekstrak Daun Seledri (Apium Graveolens L.)". J. Sains dan Teknologi Pangan, Vol. 3, No.3, P. 1297-1313, Th. 2018, http://ojs.uho.ac.id/index.php/jstp/article/view/71 21/5238.

[6] Sasmita, et al. "Waktu Penyelesaian Pengeringan, Warna Dan Kandungan Antioksidan Daun Mangkokan (Nothopanax Scutellarium) Hasil Pengeringan Hibrid Berenergi Surya-Biomasa, Tesis, Universitas Bengkulu, Bengkulu, 2016.

[7] Prastiwi, et al. "Kandungan dan Aktivitas Farmakologi Jeruk Nipis (Citrus aurantifolia s.)”. Farmaka Suplemen, Volume 15 Nomor 2, jurnal.unpad.ac.id.

[8] Hasniar, et al. "Analisis Kandungan Gizi dan Uji Organoleptik pada Bakso Tempe dengan Penambahan Daun Kelor". Jurnal Pendidikan Teknologi Pertanian, Vol 5, April Suplemen (2019) : S189-S200, https://ojs.unm.ac.id.

[9] Eden, et al. "Aktivitas Antioksidan Ekstrak Metanol Daun Mangkokan (Polyscias Scutellaria (Burn.f.)Fosberg)". Media Farmasi Indonesia, Vol 11 No 2, 1126-1135, https://stifar.ac.id/ojs/index.php/MFI/article/view/ 73/59. 